\title{
An Analysis of the Factors Influencing the Efficiency of Public-owned Colleges Run by Private Agencies
}

\author{
Yun Zhu \\ Audit department, Nanjing Normal University \\ 1 Wen Yuan Street, Nanjing 210046, China \\ E-mail: zhuyun@njnu.edu.cn \\ Nan Duan \\ Ginling College, Nanjing Normal University \\ 1 Wen Yuan Street, Nanjing 210046, China \\ E-mail: flyocarrie@126.com
}

\begin{abstract}
The public-owned college run by private agencies is a type of higher education with Chinese characteristics. It should maintain its differences from major universities and colleges, and make the most of the brand advantages to promote its blood-production function, which will bring about a sustainable development, so that it can realize the maximum efficiency in school management. The main factors influencing the efficiency of public-owned colleges run by private agencies are: the way the college is operated and managed, the way the fund is raised and the way the property rights are defined, etc. The appropriateness of these factors is also discussed.
\end{abstract}

Keywords: Public-owned colleges run by private agencies, the Efficiency in school management, Influencing factors

Public-owned colleges run by private agencies are colleges owned or controlled by the government, established by regular institutions of higher learning with the approval of the administrative departments responsible for education under the State Council and are run by private agencies. According to statistics, more than 300 of public-owned colleges run by private agencies have undertaken the task of cultivating more than $30 \%$ of the undergraduates across the country at present.

\section{The background of the appearing of public-owned colleges run by private agencies}

1.1 Since China adopted the reform and opening-up policy, the living standard of people is improving, they are moving from the stage of getting rid of poverty to leading a well off life. On the basis of the guarantee of material live, they begin to pursue the enjoyment of spiritual life. Therefore, the demand for education becomes primary. Particularly, the fever of an undergraduate education is increasing day by day. Since a nine-year compulsory education has been made universal, the income of both urban and rural residents is growing and the competition in the job market is more and more intense, the flourishing demand for higher education is stimulated. According to the 98-99 annual development report made by the World Bank, $60 \%$ of all the urban and rural individual saving deposits are owned by $20 \%$ of the citizens. The major purpose of these deposits is children's education, for which they have demand, hope and their own criteria. With the sustained growth of GDP at the rate of higher than $7 \%$, more and more people are entering a comparatively well off stage, and are heading for a well off one, and pursuing for higher education has become the strongest desire of the masses. Therefore, the original public colleges can not meet the increasing need for higher education. And this problem is sure to be more prominent.

1.2 By the end of the $20^{\text {th }}$ century, our country's economic operations have entered upon a period in which the total demand is less than the supply, the economic is turning from consumption constraining to demand constraining pattern, and the domestic hot spot of growth is disappearing. As a result, to stimulate domestic demand by developing higher education has become the strategic decision. We have initiated a new economic structure of keeping public ownership in a dominant position and have diverse forms of ownership develop side by side. And higher education should adjust to the needs for diversification of the social and economical structure. At present, Public-owned Colleges Run by Private Agencies, as an exhibition of the innovative mechanism, are seeking actively the diversification of ways to achieve 
public ownership and diverse forms of ownership in education.

1.3 The assessment indicators of educational modernization requires that the percentage of funds for education in GNP is $4.9 \%$ for world average, $5.1 \%$ for developed countries, $4.1 \%$ for less developed countries, but only $2.3 \%$ in our country. The basic situation of the country gave birth to the fact that 'poor countries run huge education systems', which means with $1.4 \%$ of the total funds for education, we are supporting an enormous education system consisting of $22.9 \%$ of the world's educated population. Our country can not afford to run higher education as in the case of compulsory education, owing to the limited financial capability of the government. As a result, it is necessary to find out new ways to develop higher education in this context.

1.4 The 21st Century Action Plan for Educational Promotion made by the Education Department has demanded people to push the enrollment rate of higher education to close to $15 \%$, making a historical leap from elite education to mass education. The acceleration of the development of higher education is both inevitable and necessary, because the number of school-age youth and the demand for higher education is increasing. Our higher education is entering a new stage, in which it is accessible to the majority of young people. The acceleration of the popularization will surely promote the higher education greatly. Therefore, the original public colleges can not meet the increasing need for developing higher education.

1.5 People have confidence in public colleges and doubt private colleges. People have confidence in public colleges because of their long histories, rich cultural spirits, excellent teaching traditions and high reputations. It is also because that they are rich in resources of human, material and money. On the contrary, private colleges are doubted, and most people would rather send their children to public colleges or universities. However, public-owned colleges run by private agencies make the best use of the advantages of being public-owned, and overcome the disadvantages of being run by private agencies, turning the possibility into reality.

1.6 According to the 47th Article of the Private Education Promotion Law of the People's Republic of China for higher education, private colleges can accept donations from citizens, legal persons or any other organizations in accordance with the related laws and regulations. The government will grant preferential tax policies to these citizens, legal persons or any other organizations according to the related rules, and will commend them.

Article 51 Investors are remunerated reasonably from the balance, after the deduction of the cost, funds reserved for development and other necessary funds that should be collected according to related regulations. The detailed ways are determined by regulations of the State Council. Since higher education is a profitable social activity, and it has been provided with powerful pledge of related laws and regulations, we believe that it will attract more investment from the public.

Consequently, it can be seen that public-owned colleges run by private agencies are implementing the strategy of rejuvenating China through science and technology to achieve educational modernization and popularization of higher education, to meet people's increasing need for higher education, and to alleviate the shortage of teaching resources resulting from the ever-enlarging scale of higher education. Thus, public-owned colleges run by private agencies emerge in this background.

\section{The concept of benefit of public-owned colleges run by private agencies}

I think the value orientation of the concept of benefit of public-owned colleges run by private agencies is that educational activities must be in line with the interest of the nation and the society, its end-result lies in the development of the students.

'Benefit is an often used concept in the development of education, it is a comprehensive assessment about the profits of educational input and output, including direct and indirect profits, and political and cultural profits. That is to say, the benefit of education is integral and comprehensive.' Although educational activities are profitable, the purpose of running a school is different from starting an enterprise. Starting an enterprise aims profits and takes maximizing profits as the criterion. However, running a school has a different purpose, and it should be in consonant with the Education Act, which state that 'educational activities must be in line with the interest of the nation and the society', 'no organization or individual can run schools or other educational institutions with a purpose of making profits.' It can be understood as rules for educational value orientation. As public welfare undertakings, public-owned colleges run by private agencies have the purpose of educating and cultivating people, raising the educational level and advancing the teaching quality. In this process, primary importance should be attached to the efficiency and benefits of education in order to promote it, and to ensure a sound development of the students. One should never distort education for his own profits. Economic benefit should be put the $2^{\text {nd }}$ place on this basis. Without certain economic benefit, colleges will lack the impetus for development, and will have difficulties to continue. However, ways of blind competition or violation of laws should not be taken. And we should follow the rule of social benefit , and put it the 3rd. If public-owned colleges run by private agencies are well run, more students will be willing to be enrolled in. As a result the reputations of these 
colleges will improve, so that the employment outlook will be brighter, and finally the economic and social benefit will increase accordingly, thus forming a virtuous circle.

\section{Factors influencing the efficiency of Public-owned Colleges Run by Private Agencies}

Public-owned Colleges Run by Private Agencies have the advantages of brands, intelligence, resources and human, so being run in traditional ways does not meet the demands and is not in conformity with market rules in terms of the investment subject and the definition of the property rights. We need to regulate them and make them self-dependent. These colleges should make full use of the advantages of brands, while remaining their differences from major colleges so that they can maintain the momentum of development, and improve their efficiency. The main factors influencing the efficiency of public-owned colleges run by private agencies are: the way the college is operated and managed, the way the fund is raised and the way the property rights are defined, etc. To establish the right concept of efficiency and to maximize the teaching efficiency, it's necessary to discuss the propriety of the above factors further.

\subsection{The relationships of between operation and scales of the public-owned colleges run by private agencies and the efficiency}

MartinTrow, an American socialist, who formulated the theory of the popularization of higher education in The Problem higher education faces in the transforming from elitism to popularization in 1973. He holds that 'there are at least 2 ways to achieve the growth of popularized higher education. One is the expansion of traditional elite universities and their traditional functions, and the other is the transformation of the university system from elitism to popularization, in order to have more diversified functions, that are new at least to universities. As a result, more people can have the access to higher education'. The public-owned college run by private agencies is a good representative of the new ways of growth. As a new form and mechanism of education, it is still in the initial stage, and has a wide space for development and revolution. In term of economy, the purpose of the public-owned college run by private agencies is to list for funds for structural reform and form a mechanism meet the requirements of the society, and to attract social funds. Market-oriented operation, greater independence, more structural innovations and diversification of managing methods are emphasized since these colleges are run by private mechanism. Today, it is necessary to integrate the public-owned college run by private agencies to speed up its development. For example, they can merger and restructure small schools with single subjects and are overlapped, in order to make them more competitive.

From 1980 to 1990, Professor Min Weifang had been in charge of the study of the different forms of development and the efficiency of scale of Chinese higher education. The study shows that when other related variables are controlled, the smaller the average scale of schools, the higher the cost per unit (the cost of cultivating a student). And the cost per unit will decrease with the increasing of the average scale of schools. When the average number of students is 4000 to 5000 , the rate of change of the cost per unit is close to 0 . This indicates that higher education has meet the demand of the efficiency of scale as a whole. Therefore in practice, undersized investment should be avoided, because it can not help to achieve efficiency of scale. At the same time, the scale should be appropriate, because of the law of supply and demand. It should be understood that the demand for education is infinite, but the supply is finite. Success will come when conditions are ripe. So we should avoid blind expansion at the cost of the quality of higher education excessive enthusiasm.

\subsection{The relationships between the way the fund is raised and the property rights are defined and the efficiency}

According to the 5th Article of the Implementing Regulations of the Law on the Promotion of Non-Governmental Education, 'the sponsors of private schools can use money, objects, land use right and intellectual property as financing for running a school'. The diversification of the form of financing will inevitably lead to the pluralism of the role of the sponsors. And according to the Education Law and the condition of public-owned colleges run by private agencies, financing can attract joint-equity educational investment from the people, who can cooperate with enterprises and institutions. Major universities can become shareholders by making full use of their brand advantages as intangible assets. Elites among supervisors and teachers can also become shareholders for they have made great contributions to the development of the college with their intelligence. This in return will give full play to their initiative and creativity in management and teaching, thus will promote the development of the college, too.

'When scales of colleges expand further, and the assets have been accumulated to a certain amount, there certainly will emerge disputes among sponsors, managers and teachers about the ownership of the property. Most colleges don't have a sponsor, and find it hard to deal with the civil dispute independently, making the main university assume endless responsibilities. A sound market operation mechanism and motivating system is not able to take shape because the property rights are not clear. Many contradictions about personnel, benefit and assets may be aroused, including law suits.' Therefore, the property rights must be made clear, so that the roles of all the parties will be definite, and the legitimate rights and interests of the country, the main university the sponsors and the colleges will be defended. The responsibilities, rights and benefits of the sponsors, managers and teachers should be specified. 


\subsection{The relationships among the goal of training, the standard of talents and the efficiency.}

An appropriate goal of training and standard of talents will contribute to the improvement of efficiency. Most public-owned colleges run by private agencies aim at cultivating international, versatile and practical talents, and they pay special attention to the cultivation of inter-disciplinary talents and specialties. We should emphasize not only the extension of knowledge, the variety of cultural backgrounds and the all-round ability of the students, but also strong professional abilities and the qualities to be competent for a job. The experience of talent models from private schools can be learnt from.

The social assessment system for talents from public-owned colleges run by private agencies should be established. The supervision of their order and their behavior should be strengthened to ensure the quality of the talents and the efficiency of the school.

\subsection{The relationships among the specialties and the readjustment of the curriculum and the efficiency.}

With the support of the main university and the private agencies, public-owned colleges run by private agencies blaze new trails in offering specialties by breaking the bonds of conventions when classifying the specialties, such as blurring boundaries between some specialties and grafting some of them. These colleges should also give prominence to the form of individuality in education, for example, to enroll students on a large platform, and to allow them to choose their specialties by themselves later. And these colleges should pay more attention to the development of the specialties and its close relations with the demand of the society and the market. It's better for public-owned colleges run by private agencies to avoid overlapping of specialties, copying the specialties of the main university or trying to be small and all-inclusive to form their own system. It's also necessary for them to avoid catering the market too much, or being shot-sighted, ignoring a sustainable development. Otherwise, it will result in low efficiency.

The management of education should follow the rules of education. And the supervising of the quality and the level of teaching should be strengthened. Public supervision should be carried out, including the supervision of the administration, the process and the result of the education. Following the principle of wide-in and strict-out, public-owned colleges run by private agencies must avoid teaching in a rough way and issuing diplomas recklessly.

\subsection{The relationships among the personnel management and the development of teaching troops and the efficiency}

Public-owned colleges run by private agencies embodying the characteristics of the private mechanism, should make the transformation of the mechanism as a core. By reforming personnel and distribution systems, these colleges can put the managing system in order, strengthen the awareness of position, and set post according to demand. They also can adopt a system of contract and pay wages according to the specific post. These will enable them to form a flexible incentive mechanism, and to create an institutional environment which will favor a faster growing of the elitists and will encourage them to make breakthroughs. At the same time, the stability of the teaching and managing staff must be optimized, and the quality of teaching must be improved, so that the teaching efficiency and the overall level will be upgraded.

When we are developing the teaching troops, importance should be given to a proper age structure and knowledge structure of the teachers. These days, in some public-owned colleges run by private agencies, the structure is single and aging, with low academic degrees and low social recognition on the whole. And in some others, the teacher-student ratios become extreme as they are expanding.

I propose to establish a regional teacher bank to allow higher education institutions to share teaching resources, including overseas teaching resources. On the basis of voluntary participation and mutual benefit, colleges and universities can improve the teaching level and efficiency by cooperating and complementing, and by interdisciplinary efforts and optimizing the overall capacity.

\subsection{The relationships among resource utilization, financial managing system and the efficiency.}

In the utilization of teaching resources, public-owned colleges run by private agencies make full use of the material and human resources of the main university. And with the operation of private agencies, they make use of, expand, liquidize and optimize these high-quality resources of higher education (material, human and intangible assets), and offer paid use of them. However, some of those colleges overuse the resources of the main university, this in the long run will undermine the sustainable development of the main university, including tainting its and reputation, destroying its brand and lowering its efficiency.

The core of financial management of public-owned colleges run by private agencies is to achieve their goals by raising and using the money of the right amount at the right time. In this process, the value of the college should be maximized, efforts of all parties should be coordinated, the money should be well allocated, risks must be evaded and the efficiency should be improved. We must reinforce the economic responsibility, because financial supervision is the fundamental guarantee of the efficiency, and can ensure that the financial management is going on smoothly in the college.

Public-owned colleges run by private are supposed to offer different financing channels, make full use of their own 
resources and mobilize people of different classes to increase educational investment. The management of the colleges should not only benefit the proper utilization of the educational resources as a whole, to avoid duplicated waste resulting from self-seclusion, but also avoid the harmful tendency of seeking after high standards and extravagance. On the contrary, these colleges should maximize the efficiency by improving distribution and utilization.

\section{References}

Guo, Xiaowen. (2006). Where Does Educational Industrialization Go. [Online] Available: http://www.cvedu.com.cn/url/index.asp

Hu, Ruiwen. (2001).The Latest Developments In Higher Education In Our Country and The Problem Of Financing In Colleges Run by Private Agencies. Journal of Zhejing Shu Ren University, (2).

Martin, Trow. (1999).The Problem Higher Education Faces in the Transforming from Elitism to Popularization. Foreign Materials on Higher Education, (1).

Min, Weifang. (1994). The Investment in Education and the Efficiency-The Study of Education Economics by Professor Min Weifang. Peking University Journal: Philosophy and Social Science, (4).

Pan, Maoyuan. Forming a Comprehensive Concept of Efficiency In Education. Pan Maoyuan's Collected Works about Higher Education. University of Shantou: Publishing.

Yang, Ming. (2000). How Far Is Chinese Education from Modernization. The Study of the Development of Education, (8).

Zhu, Zhenguo. (2004). A seminar on the Prospect of Private Colleges. Guang Ming Daily: Education Weekly, 13 May. 